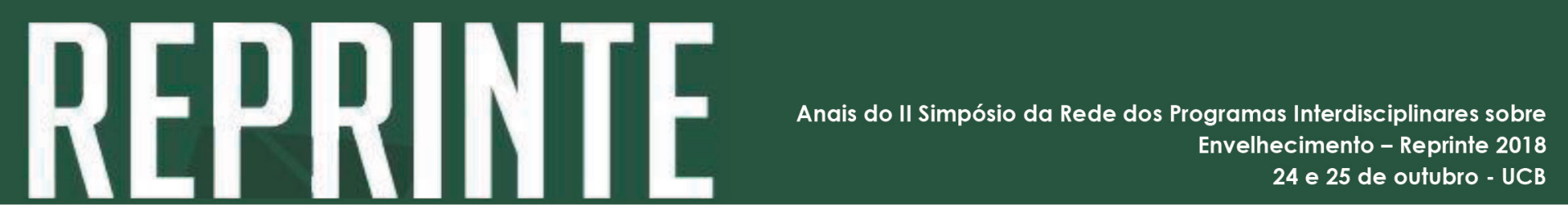

http://dx.doi.org/10.5335/rbceh.v16i1.9788

\title{
2) Avaliação de Obesidade Sarcopênica em Idosos Acompanhados no Centro Especializado de Diabetes, Obesidade e Hipertensão do Distrito Federal
}

Fernanda Farias ${ }^{1}$

\section{Resumo}

Considerada como um dos maiores problemas de saúde pública do mundo, que vem crescendo anual no Brasil, obesidade tem alta prevalência na população acima de 18 anos no Distrito Federal. É considerado obesidade quando ocorre a combinação entre o Índice de Massa Corporal (IMC) e a distribuição de gordura corporal pelo corpo do indivíduo. Caracteriza-se pelo aumento de massa adiposa associada com redução de massa muscular esquelética (MME), sendo chamada de "obesidade sarcopênica", que vai aumentando com a idade.

Palavras-chave: Obesidade sarcopênica. Idosos. Prevalência.

\section{Introdução}

A obesidade é um dos maiores problemas de saúde pública do mundo e vem crescendo ano a ano no Brasil. A pesquisa Vigitel 2016 demonstrou uma prevalência de 16,7\% de obesidade na população acima de 18 anos no Distrito Federal. Segundo a I Diretriz Brasileira de Obesidade a melhor opção para o reconhecimento da obesidade é a combinação entre massa corporal avaliada pelo Índice de Massa Corporal (IMC) e a distribuição de gordura corporal que pode ser realizada a partir da impedância bioelétrica (BIA). Nos últimos anos tem-se percebido que indivíduos obesos apresentam aumento de massa adiposa associada com redução de massa muscular esquelética (MME), quadro esse denominado "obesidade sarcopênica". A sarcopenia que normalmente relaciona-se com o aumento da idade agora também vem sendo identificada em outras faixas etárias.

Nutricionista e Mestre em Saúde do Idoso, pela Fundação de Ensino e Pesquisa em Ciências da Saúde do Distrito Federal (Fepecs). Endereço para correspondência: SMHN Quadra 03, conjunto A, Bloco 1 Edifício Fepecs. 70.710907. Brasília, DF, Brasil. Email: mestradofernandafarias@gmail.com 


\section{Método}

Avaliou-se o estado nutricional, por meio do IMC e da BIA, de todos os indivíduos adultos e idosos que participaram das atividades coletivas propostas pelo Programa de Tratamento de Obesidade do Centro Especializado em Obesidade, Diabetes e Hipertensão do Distrito Federal (CEDOH) durante o mês de agosto de 2018 e usou-se os critérios diagnósticos propostos por Kim et al (2014).

\section{Resultados}

Dos 21 indivíduos avaliados, todos apresentaram obesidade grau 2 ou 3 segundo pontos de corte propostos pela Organização Mundial de Saúde e 80\% apresentou aumento de massa gordurosa associada com redução de MME segundo Kim et al (2014).

\section{Conclusão}

Faz-se importante identificar se o excesso de peso curso com redução de massa muscular para que o tratamento dietoterápico seja otimizado e adequado não apenas para a redução do peso corporal mas também para a recuperação de um estado sarcopênico associado.

\section{Evaluation of Sarcopenic Obesity in Elderly Accompanied in the Specialized Center of Diabetes, Obesity and Hypertension of the Federal District}

\section{Abstract}

Considered one of the biggest public health problems in the world, which is growing yearly in Brazil, obesity has a high prevalence in the population above 18 years of age in the Federal District. Obesity is considered when the combination of the Body Mass Index (BMI) and the distribution of body fat by the individual's body occurs. It is characterized by the increase of adipose mass associated with reduction of skeletal muscle mass (MME), being called "sarcopenic obesity", which increases with age.

Keywords: Sarcopenic Obesity. Seniors. Prevalence.

\section{Referências}

KIM, TN. et al. Impact of Visceral Fat on Skeletal Muscle Mass and Vice Versa in a Prospective Cohort Study: The Korean Sarcopenic Obesity Study (KSOS). PLoS ONE, Estados Unidos, v. 9, n. 12, p. 1-13, 2014. 